\title{
Estimating Human Capital Stock In Korea
}

Nam Chul Lee, (E-mail: nclee @ krivet.re.kr), KRIVET and Dankook University, Korea

\begin{abstract}
This paper presents a labor income based measure of Korea's human capital stock from 1963 to 2000. For this purpose, I use all available basic statistics to compile consistent time series data on wage rates, average working hours by industry, composition of workers cross-classified by industry, educational attainment, sex, and class of employment. I present of estimates of human capital stock for all industries without considering class of employment and considering class of employment. Because the wage data for self-employed and family workers are not available, I devise estimates of human capital stock separately depending on the assumption for the wage differential by class of employment. In the case of all industries without considering class of employment, the aggregate volume and quality of labor input increased at an average rate of 3.73 percent and 0.84 percent per year, respectively, during the 1963-2000. Consequently, approximate 23 percent of the growth of labor volume can be attributed to improvement in labor quality from 1963 to 2000 . When 75 percent of the wage rates of employees is assumed to apply for unpaid workers, the aggregate volume and quality of labor input increased at an average rate of 3.99 percent and 1.10 percent per year, respectively, during the 1963-2000 in all industries with considering class of employment. Consequently, approximate 28 percent of the growth of labor volume can be attributed to improvement in labor quality during the 38 years period.
\end{abstract}

\section{INTRODUCTION}

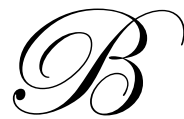

ecker (1964), Mincer (1974), and Schultz (1961) provided the emergence of the economic growth literature in terms of human capital. They have found it useful to characterize the benefits of education by means of the notion of investment in human capital. Conceptually, human capital input is labor input in production adjusted for quality in terms of education, training, and health. Human capital stock is heterogeneous. No single type of characteristic can adequately represent the many human attributes that bear on economic activity. It is also important to acknowledge that human capital takes many forms, and is in practice more than the sum of its parts, and that the identification and measurement of a finite number of specific skills cannot provide a complete account of human capital stock. Recent empirical studies of growth have attempted to assess the role of human capital as a determinant of long-term economic performance using measures of human capital based on, among other things, school enrollment, ${ }^{1}$ average years of schooling, ${ }^{2}$ literacy rates, ${ }^{3}$ educational attainment, ${ }^{4}$ and income based approach. ${ }^{5}$

School enrollment ratios are used as a proxy for human capital accumulation. However, they introduce measurement errors related to the presence of repeater and dropout rates over time. School enrollment rates are measures of the flow of investments in human capital, rather than its stock. While net enrollment ratios are more appropriate for estimating human capital accumulation, gross enrollment ratios are typically used due to their wider availability.

\footnotetext{
1 See Barro (1991), Mankiew, Romer, and Weil (1992).

2 See Psacharopoulos and Arriagada (1986, 1992), Lau, Jamison and Louat (1991), Barro and Lee (1993), Nehru,Swanson and Dubey (1995).

${ }^{3}$ See Romer (1989), Azariadis and Drazen (1990).

${ }^{4}$ See Kyriacou (1991), Psacharopoulos and Arriagada (1986).

${ }^{5}$ See Mulligan and Sala-i-Martin (1997).
} 
Average years of schooling so widely used in human capital measures are utilized both aggregate data and micro data. There are two reasons that come to mind immediately. First, average years of schooling is a useful indicator of capital accumulation. Particularly when there are no other readily available measures either for individuals or with economy wide time series. Particularly, in cross-country comparisons, average years of schooling is often the only feasible measure. Second, there is a theoretical argument that indicators that average years of schooling is a measure of the stock of human capital under a reasonable set of assumptions. However, average years of schooling is far from a perfect measure of the stock of human capital. First, estimates of the returns to schooling are sensitive to the correct specification of investment costs, but the overall conclusions concerning the importance of schooling are robust. Especially, average years of school lacks a quality element. It is also impossible to compute the return on human capital investment using their measures. Second, schooling produces only a part of the stock of capital. Some economists estimated that investment in on-the-job training produces 39 percent of the human capital. Finally, this measure does not assume that the productivity differential among workers is proportional to the differential in educational attainment. It also strives to capture differences in quality of education as well as the market relevance of different types of education and of working experience.

Educational attainment can be a useful tool for comparing one feature of the human capital stock. However, there are several limitations with educational attainment as a proxy for human capital. First, even though there may be some correlation between educational attainment and relevant skills, knowledge, and competence, school completion does not guarantee these attributes. Attainment only certifies education undertaken as part of a completed cycle of formal education. It ignores, for example, learning on courses that do not lead to a recognized qualification or less formal adult education, as well as enterprise-based training. Second, because skills can depreciate, and third, because it can be hard to compare attainment by economic category. Finally, educational attainment of the population aged 25-64 shows percentage who have gained upper-secondary and tertiary level qualifications. Internationally standardized measure of educational level reached. But it does not measure any specific set of knowledge and skills.

Literacy rates give an indication of educational mobility between generations, which has a bearing both one quality of opportunity and the prospect of improving overall human capital stock. Literacy is a stock variable, but it involves important empirical problems, for instance, it does not account for the contribution of higher levels of education which tend to be crucial to productivity increases and, therefore, to aggregate economic growth.

The issue is simply whether capital should be measured by its market value or by investment costs. The measure suggested in this paper-a labor-income based measure-uses the market value of capital services to measure the capital stock. It contrasts this measure with the use of the number of years of schooling as an indicator of the stock of human capital. Labor-income-based measures of human capital stock only take account of the market value of human capital. Labor-income-based measures of human capital stock ${ }^{6}$ only take account of the market value of human capital. There are some drawbacks in the ways which compute human capital. One major drawback is that they utilize some assumptions. Specifically, the relative wage weights used in their construction are a true reflection of productivity differences due to schooling if labor with different years of schooling are perfect substitutes. The second potential source of problems could be assumption that the uneducated are perfect substitutes for the rest of the labor force. Furthermore, there are many other elements of human capital investment-parental inputs, on the job training, health investments- which are likely to be related to the level of schooling investments.

Thus, estimates of the effects of schooling investments on earnings can be biased. Mulligan and Sala-iMartin (1995) have used a measure based on educational attainment of the labor force and the share of different groups in labor income. They found that across states in the United States, those with the lowest level of human capital stock in the initial period had the highest growth over time. They also found that for the period 1940-90, the stock of human capital grew twice as quickly in the United States than would have indicated by measures based on average years of schooling alone. However, some States which have lots of schooling do not have very high stocks of human capital.

\footnotetext{
${ }^{6}$ Income-based as a measure of aggregate human capital input for a given state in a given year the aggregate labor income divided by the average income of workers with no schooling for that years and in the state.
} 
Many researches have developed measures of the stock of human capital to facilitate empirical studies on the role of human capital for cross-country growth comparisons. ${ }^{7}$ Although cross-country research focuses on the broadest possible sample of human capital measure, it is unable to capture some of the key dimensions. ${ }^{8}$ In Korea, few attempts have been made to measure the stock of human capital. Kim and Park (1985) estimated labor indices for whole industries during the 1963-1992. Lee and Kim (1993) measured of human capital stock in Korea over the period 1963-1993. To examine the change of composition of the work force and accumulation of human capital, this research has constructed indices of labor input. ${ }^{9}$

This paper presents a labor income based measure of Korea's human capital stock from 1963 to 2000. This study tries to provide a more precise and consistent measure of the human capital stock of Korea over the period 1963-2000. For this purpose, I use all available basic statistics to compile consistent time series data on wage rates, average working hours by industries, composition of workers cross-classified by industry, educational attainment, sex, and class of employment. I present of estimates of human capital stock for industry as a whole in terms of all industries with considering class of employment and considering class of employment. Because the wage data for self-employed and family workers are not available, I devise estimates of human capital stock separately depending on the assumption for the wage differential by class of employment.

The contribution of this study can be found in that it analyzed various common measurement methods for human stock capital used both at home and abroad and used a new model to measure Korea's human capital stock accumulation from 1963 to 2000 . In doing so, I did my best to correctly measure changes in labor quality by analyzing a time series on changes in the workforce and by fully utilizing all available statistical data by sex, educational attainment, industry, and class of employment.

The remainder of this paper is organized as follows. In Section 2, I describe econometric methodology. In Section 3, I analyze the estimation results. In Section 4 concludes.

\section{ECONOMETRIC METHODOLOGY}

Measuring human capital stock is notoriously difficult. I describe now my methodology of creating time series data on the human capital stock of Korea. Human capital stock was measured by a translog function based on total labor input $(L)$ that assumes elasticity of substitution between individual components ( $L i$ ) (Christensen, Jorgenson and Lau, 1971). The translog function is the second approximate value of a random second-order differential possibility function on a Taylor's series expansion.

All workers of the domestic economy in each year were classified by industry, class of employment, education attainment, and sex. The components are distributed among 270 cells. ${ }^{10}$ The 270 cells were determined based on the following equation; 9 (industry) $* 3$ (class of employment) $* 5$ (education attainment) $* 2$ (sex). If I assume that labor quality is consistent for each component, individual component can be expressed by multiplying the number of workers $H i(t)$ by labor hours $(H)$. Where Hit represents labor hours multiplied by the number of workers at time $t$ for the 270 cells. In addition, it is also possible to calculate by multiplying labor quality by total labor hour. The aggregate labor input indexes represent numeric values of changes in the volume of labor input provided by all

\footnotetext{
${ }^{7}$ See, for example, Barro Lee (1996), Barro (1991), Mulligan and Sala-i-Martin (1995), Nehru et al. (1995), Psacharopoulos and Arriagada (1992).

${ }^{8}$ For a cross-country study of measures of human capital and their limitations, See OECD (1998).

9 Characteristics of individual workers were classified with sex (2), educational attainment (5), industry (9), and class of employment (2). ( ) means classification of the work force.

${ }^{10}$ Industry (9)-Agriculture-fishery; Mining; Manufacturing; Electricity, gas and water; Construction; Wholesale and retail trade, restaurants and hotels; Transport, storage and communication; Finance, insurance, real estate; Community, social and personal services. Class of employment (3)- employees, self-employed, and family employees. Educational attainment (5)- primary school, middle school, high school, junior college, and college. Sex (2)- male, female.
} 
workers in the economy. An assumption was made that aggregate labor input can be expressed as a translog function that takes for granted consistent elasticity of substitution between individual components.

The weighted average method could be used to indicate the average proportion of a certain individual component to wage value of labor. And the rate of changes in input were determined by applying the weighted average method to changes in 270 individual components classified by sex, age, education level and class of employment. The weighted average values indicate the proportion of each component's labor income to total labor income of a given economy. They play a crucial role for measuring human capital along with changes in the workforce stemming from substitution between individual components for production.

The concept of partial index of labor input was carried to index the impact of substitution between individual component on the aggregate volume and quality of labor input. I estimated first-order partial indexes that would indicate changes in total labor input stemming from substitution between individual components when taking into account only one of the four categories, namely, sex, class of employment, industry, and educational level. Meanwhile, the econometric method was used to derive needed primary detail data from the 1963 - 1970 lacking detailed statistics on, for instance, workers, labor hours and wages. The following describes the analysis method in detail. First, unit-root and co-integration tests were performed for the 1971 to 2000 data. Based on the result, the long-term relationship between time series was estimated by a regression model. Next, the regression model was used to generate details that would complement deficiencies in the 1963 - 1970 data. In doing so, unit roots and cointegration were tested by the augmented Dickey-Fuller (ADF) method and the Engle and Granger method, respectively.

I selected a regression model by carefully examining significance of explanatory variables and degree of freedom in consideration of data extension. Typical determination coefficients (R-square) were mainly examined for the degree of fitness aspect while the significance of explanatory variables was examined by the $t$ test. When it was not possible to find out the long-term relationship between time series, univariate time series models, such as the ARIMA model developed by Box and Jenkins, were set and time series of the past were extended accordingly. Final data were revised by considering series determined based on econometric models, ratios between industries, etc.

I express the aggregate volume of labor input (L) as a translog function of its individual components, so that the growth rate of labor volume is a weighted average of the growth rates of its components as shown in Equation (1) (Christensen, Jorgenson and Lau, 1971).

$\ln L(\mathrm{t})=\alpha_{0}+\sum_{i} \alpha_{i} \ln L_{i}(t)+\frac{1}{2} \sum_{j} \sum_{k} \gamma_{j, k} \ln L_{j}(t) L_{k}(t)$

where $\sum_{t \geq 1} \alpha=1, \gamma_{j, k}=\gamma_{k, j} \sum_{k} \gamma_{j, k}=0$ and $L_{j}$ and $L_{k}$ are industry (9)*class of employment (3)* level of educational attainment (5)* $\operatorname{sex}(2)$.

This translog production function is the second result of random quadratic differentials possibility function (Talyor expansion). I can derive by quadratic approximation lemma (Dievert,1976) of translog function.

$\ln L_{i(t)}-\ln L_{i(t-1)}=\sum_{i=1}^{270} \frac{1}{2}\left(v_{i, t}+v_{i, t-1}\right)\left(\ln L_{i}(t)-L_{i}(t-1)\right)$

where $v_{i, t}$ and $v_{i, t-1}$ are the proportion of labor income by $i^{\prime}$ th factor labor income at time $t$. 


$$
v_{i, t}=\frac{w_{k}(t) L_{k}(t)}{\sum_{k} w_{k}(t) L_{k}(t)}, k=1,2, \cdots, 270
$$

Where $\mathrm{W}$ is labor income. Equation (2) can be written as :

$\Delta \ln L(t)=\sum_{i=1}^{270} \frac{1}{2}\left(v_{i, t}+v_{i, t-1}\right) \Delta \ln L_{i}(t)$

Where $\frac{1}{2}\left(v_{i, t}+v_{i, t-1}\right)$ denots the share of each component in labor income of whole economy. They play an important role for measuring human capital stock along with change rate of the component proportion in employees stemming from substitution between workforce's components for production and is the kind of Divisia index. ${ }^{11} 270$ components can be classified by each component as follow equation (5):

$$
\begin{aligned}
\Delta \ln L(t) & =\sum_{i=1}^{9} \sum_{c=1}^{3} \sum_{e=1}^{5} \sum_{s=1}^{2} \frac{1}{2}\left(v_{\text {ices }, t}+v_{\text {ices }, t-1}\right) \Delta \ln L_{\text {ices }}(t) \\
& =\sum_{i=1}^{9} \sum_{c=1}^{3} \sum_{e=1}^{5} \sum_{s=1}^{2} \frac{1}{2}\left(v_{\text {ices }, t}+v_{\text {ices }, t-1}\right) \Delta \ln H_{\text {ices }}(t)
\end{aligned}
$$

Where $v_{\text {ices }, t}=\frac{w_{\text {ices }}(t) L_{\text {ices }}(t)}{\sum_{i} \sum_{c} \sum_{e} \sum_{s} w_{\text {ices }}(t) L_{\text {ices }}(t)^{\prime}} \quad i$ : industry, s : sex, c: class of employment, e : educational attainment.

If I assume that labor quality is consistent in each component, labor input of component can describe following as $L_{i}=$ working hours * number of workers $=H_{i}(t)$. Where $\mathrm{Hi}(\mathrm{t})$ is labor hours multiplied by the number of workers at time $t$ for the 270cells. Aggregate labor input is possible to describe by multiplying by total labor hour.

$Q(t)=L(t) / H(t)$

Where $H(t)=\sum_{i} H_{i}(t)$. So, $\Delta \ln Q(t)=\Delta \ln L(t)-\Delta \ln H(t)$

The first - order partial index of the volume of labor input corresponding to one specific characteristic captures the effect of the substitutions among individual workers classified only one of the sex, class of employment, industry, and educational attainment.

${ }^{11}$ Where Vit $=$ labor income $i^{\prime}$ th are at time $t . \log \frac{H_{t+!}}{H_{t}} \equiv \sum_{i=1}^{N}\left(\frac{v_{i, t}+v_{i, t+1}}{2}\right) \log \frac{\chi_{i, t+1}}{\chi_{i, t}}, \quad v_{u, t} \equiv \frac{\partial \log F}{\partial \log \chi_{i}} \mid \mathrm{X}=\mathrm{X} t$ 


$$
\begin{aligned}
\Delta \ln L_{s}(t) & =\sum_{s=1}^{2} \frac{1}{2}\left(v_{i, t}^{s}+v_{i, t-1}^{s}\right) \Delta \ln H_{s}(t) \\
& =\sum_{s=1}^{2} \frac{1}{2}\left(v_{i, t}^{s}+v_{i, t-1}^{s}\right) \Delta \ln \sum_{i} \sum_{c} \sum_{e} H_{i c e s}(t)
\end{aligned}
$$

Here, $v_{i, t}^{s}=\sum_{i} \sum_{c} \sum_{e} v_{\text {ices' }}$ where $i$ : industry, $s:$ sex, c: class, $e$ : educational attainment.

So, labor quality can derive as equation (8) and (9):

$$
Q_{s}(t)=L_{s}(t) / H(t) \quad H(t)=\sum_{s} \sum_{i} \sum_{c} \sum_{e} H_{\text {ices }}(t)
$$

$\Delta \ln Q_{s}(t)=\Delta \ln L_{s}(t)-\Delta \ln H(t)$

\section{EMPIRICAL RESULTS}

The number of workers, labor hours and wages by industry, sex and education level from 1963 to 2000 were used to measures the human capital stock of the Korean economy as a whole industry. Human capital stock was also accounted classified by employment status (either employee or unpaid worker). But because it was not possible to get relevant information on labor hours and wages for the self-employed and family workers who fall under the unpaid worker category, human capital stock was estimated based on an assumption that the labor income of the selfemployed or a family worker is equivalent to $75 \%, 50 \%$ or $25 \%$ of an employee (permanent worker, temporary worker, and part-time worker). Then, the human capital stock was analyzed in comparison with human capital stock determined without considering employment status.

\section{When Worker Classification By Class Of Employment Was Not Considered}

When calculating by not classifying workers by employment status and by applying same average monthly wages, I analyzed that the rate of average monthly increase as well as partial index of labor input by sex, education level and industry from 1963 to 2000. First-order partial indexes that take into account only one of sex, employment status, industry, and educational level categories could be determined by the weighted average method assuming that labor quality differs only at the preliminary classification stage. Here, labor quality could be determined by the method used to calculate. Its analysis is provided in $\langle$ Table 1$\rangle$.

Table 1 - Annual Average Growth Rate of Labor Input: All Industries (1963 - 2000) (Unit : \% )

\begin{tabular}{|c|c|c|c|c|c|c|c|c|c|c|c|c|}
\hline & \multicolumn{2}{|c|}{ Aggregate Labor Input Index } & \multicolumn{2}{|c|}{ Gender Partial Index } & \multicolumn{2}{|c|}{ Education Partial Index } & \multicolumn{3}{|c|}{ Industry Partial Index } \\
\hline Year & $\begin{array}{c}\text { Total } \\
\text { Labor } \\
\text { Input }\end{array}$ & $\begin{array}{c}\text { Total } \\
\text { Labor } \\
\text { Hour }\end{array}$ & $\begin{array}{c}\text { Quality } \\
\text { of Labor }\end{array}$ & $\begin{array}{c}\text { Total } \\
\text { Labor } \\
\text { Input }\end{array}$ & $\begin{array}{c}\text { Total } \\
\text { Labor } \\
\text { Hour }\end{array}$ & $\begin{array}{c}\text { Quality } \\
\text { of Labor }\end{array}$ & $\begin{array}{c}\text { Total } \\
\text { Labor } \\
\text { Input }\end{array}$ & $\begin{array}{c}\text { Total } \\
\text { Labor } \\
\text { Hour }\end{array}$ & $\begin{array}{c}\text { Quality } \\
\text { of Labor }\end{array}$ & $\begin{array}{c}\text { Total } \\
\text { Labor } \\
\text { Input }\end{array}$ & $\begin{array}{c}\text { Total } \\
\text { Labor } \\
\text { Hour }\end{array}$ & $\begin{array}{c}\text { Quality } \\
\text { of Labor }\end{array}$ \\
\hline $63-00$ & 3.73 & 2.89 & 0.84 & 2.41 & 2.89 & -0.48 & 3.96 & 2.89 & 1.07 & 3.22 & 2.89 & 0.34 \\
\hline $63-70$ & 4.10 & 3.69 & 0.41 & 3.17 & 3.69 & -0.52 & 5.09 & 3.69 & 1.39 & 3.35 & 3.69 & -0.35 \\
\hline $71-80$ & 5.51 & 4.26 & 0.89 & 3.35 & 4.26 & -0.91 & 4.90 & 4.26 & 0.64 & 5.26 & 4.26 & 1.00 \\
\hline $81-90$ & 3.45 & 2.39 & 1.05 & 1.98 & 2.39 & -0.41 & 3.71 & 2.39 & 1.31 & 2.72 & 2.39 & 0.33 \\
\hline $91-00$ & 2.32 & 1.43 & 0.89 & 1.35 & 1.43 & -0.08 & 2.47 & 1.43 & 1.03 & 1.61 & 1.43 & 0.17 \\
\hline
\end{tabular}


An analysis of aggregate labor input, labor hour, and labor quality for whole industries shows us that aggregate labor input increased by average 3.73\% annually between 1963 to 2000 and the labor quality index went up by average $0.84 \%$ annually during the same period. ${ }^{12}$ An empirical analysis yielded rates of increase (logarithmic differentials) based on translog indexes of method. Therefore, I can see that $23.0 \%$ increase of the aggregate labor input for the observation period is attributable to improved labor quality or accumulated human capital. ${ }^{13}$ Increases in $L$ contributed to the improvement of labor quality by the following ratios: $10.0 \%$ (1963 to 1970), $16.0 \%$ (1971 to 1980), $30.0 \%$ (1981 to 1990) and $38.0 \%$ (1991 to 2000).

Examining the relationship between aggregate labor input during the period and index of labor quality, aggregate labor input had increased between 1963 and 1980, but began falling since 1981. Labor quality showed a downward/upward trend exactly the same as that the between 1963 and 2000. It should be noted, however, that the increases in aggregate labor input are attributable to the qualitative improvement of labor and that human capital continuously increased by $10.0 \%$ between 1963 and 1970, by $16.0 \%$ between 1971 and 1980, by 30.0\% between 1981 and 1990 and by $38.0 \%$ between 1991 and 2000 . Which means that labor quality was improved by the accumulation of human capital stemming from better education despite decreasing labor hours during the observation period in Korea. Meanwhile, partial indexes were determined for sex, education level, and industry categories, which all affect human capital accumulation. Partial indexes are based on an assumption that labor quality differs only for factors under observation, such as sex, education level, and industry, and remain unchanged for all other factors. The effect of the partial indexes on human capital accumulation is summarized in <Table 1$\rangle$.

Table 1 shows that the labor quality index climbed down by $0.48 \%$ due to changes in structure of sex ratios between 1963 and 2000. Although the rate of economic participation in women increased to $48.3 \%$ in 2000 from $41.7 \%$ in 1977, the figures are still way below those for men $78.7 \%$ in 1977 and $74.0 \%$ in 2000 . Furthermore, female workers earned only $64.8 \%$ of what their male counterparts earned in 2000.

The survey result is ascribed to the fact that female workers' wages remained relatively low despite their increasing participation in economic activities during the observation period. The quality of labor index, which had declined drastically due to changes in sex ratios during the 1960s and the 1970s, fell by a smaller margin during the next two decades probably due to improved working conditions, such as higher wages and higher education level for women.

Between 1963 and 2000, changes in educational level resulted in average 1.07\% increases in the quality index annually, thus contributing more to quality index increases than any other factors. This brings us to a conclusion that strong emphasis on education, more learning opportunities and better conditions for education drove human capital accumulation in Korea. In the meantime, the quality index edged up by $0.34 \%$ on average annually due to changes in industrial structure. The index, which had declined by average $0.35 \%$ annually between 1963 and 1970, showed an upward trend thanks to changes in industrial structure after the 1970s. The trend was brought about presumably by economic emphasis that began shifting from the agricultural industry to the manufacturing and service sectors with higher wage levels after the 1970s. The industrial data for 1963 shows that the agriculture and fishing industries employed by far the most number of people accounting for $63.0 \%$ of the domestic economy followed by mining and manufacturing (8.7\%), social overhead capital (SOC), and other services (28.35\%). As of 2000, agriculture and fishery's share stood at 10.8\%, a huge decease from 1963, while mining and manufacturing and SOC and other services accounted for $20.17 \%$ and $69.0 \%$, respectively (National Statistical Office, 2001).

\section{When Worker Classification By Class Of Employment Was Considered}

The proportion of employees (permanent, temporary and part-time worker) to the total domestic workforce has been increasing drastically and continuously. There were 2.83 million employees in 1963, 3.75 million in 1970,

12 Please refer to appendix $\mathrm{C}$ for annual aggregate labor input indexes, partial indexes by sex, partial index by educational attainment, and partial index by industry from 1963 to 2000 .

${ }^{13}$ Increases in aggregate labor input contributed to the improvement of labor quality by the following ratios: 10.0\% (1963 -1970), $16.0 \%$ (1971-1980), 30.0\% (1981-1990) and 38.0\% (1991-2000). 
6.46 million in 1980, 10.95 million in 1990 and 13.14 million in 2000. Employees accounted for 31.5\%, 40.0\%, $47.2 \%, 60.5 \%$, and $62.4 \%$ of the total domestic workforce in 1963,1970, 1980, 1990, and 2000, respectively. The proportion of unpaid workers to the total workforce was $68.5 \%$ in $1963,61.1 \%$ in $1970,52.8 \%$ in $1980,39.3 \%$ in 1990, and 37.6\% in 2000, exhibiting a continuous downward trend according to an Annual Report on the Economically Active Population Survey prepared by the Korea National Statistical Office (KNSO).

And the proportion of the self-employed to unpaid workers went up continuously $54.4 \%$ in $1963,60.0 \%$ in $1970,64.4 \%$ in $1980,71.3 \% \%$ in 1990 , and $75.7 \%$ in 2000 , while the proportion of family workers to unpaid workers showed the opposite trend $45.6 \%$ in $1963,44.0 \%$ in $1970,35.6 \%$ in $1980,29.1 \%$ in 1990 , and $24.3 \%$ in 2000 . The self-employed accounts for a fairly large portion of the workforce in Korea although an exact comparison with other economies is difficult because the definition of the self-employed is different country to country. While the proportion of the self-employed to the total workforce was approximately $28.4 \%$ in Korea in 2000 , the figures were about $8.3 \%$ in the United States, 9.5\% in Germany, and $11.8 \%$ in Japan in $1996 .{ }^{14}$ Changes in the workforce noted above give rise to the need to study the effect of employment status changes on human capital accumulation.

Table 2 - The Proportion of Employees and Unpaid Workers in Total Workers (Unit: 1,000,\%)

\begin{tabular}{|c|c|c|c|c|c|}
\hline & \multirow{2}{*}{ Total Workers } & \multirow{2}{*}{ Employees } & \multicolumn{3}{|c|}{ Unpaid Worker } \\
\cline { 3 - 6 } & & & Total & Self Employed & Family Employees \\
\hline 1963 & 7,563 & $2,383(31.5)$ & $5,178(68.5)$ & $2,817(54.4)$ & $2,361(45.6)$ \\
\hline 1970 & 9,617 & $3,746(40.4)$ & $5,872(61.1)$ & $3,286(60.0)$ & $2,586(44.0)$ \\
\hline 1980 & 13,683 & $6,464(47.2)$ & $7,220(52.8)$ & $4,651(64.5)$ & $2,569(35.6)$ \\
\hline 1990 & 18,085 & $10,950(60.5)$ & $7,105(39.3)$ & $5,068(71.3)$ & $2,067(29.1)$ \\
\hline 2000 & 21,061 & $13,142(62.4)$ & $7,910(37.6)$ & $5,990(75.7)$ & $1,920(24.3)$ \\
\hline
\end{tabular}

Source : Notional Statistics Offices (various years), Annual Report on Economic Activity.

Note: Proportion of Self-employed and Family employees is for total unpaid workers.

In Tables 3, 4, and 5, an assumption was made that the average monthly wage of the self-employed or a family worker belonging to the unpaid worker category is $75 \%, 50 \%$ or $25 \%$ of an employee's and labor incomes were calculated accordingly.

Table 3 - Annual Average Growth Rate of Labor Input:

$75 \%$ of the Employees Wage for Unpaid Wo r k e r s (Unit: \%)

\begin{tabular}{|c|c|c|c|c|c|c|c|c|c|c|c|c|}
\hline & \multicolumn{3}{|c|}{ Aggregate Labor Input } & \multicolumn{3}{|c|}{ Gender Partial Index } & \multicolumn{2}{|c|}{ Education Partial Index } & \multicolumn{3}{|c|}{ Industry Partial Index } \\
\hline Year & $\begin{array}{c}\text { Total } \\
\text { Labor } \\
\text { Input }\end{array}$ & $\begin{array}{c}\text { Total } \\
\text { Labor } \\
\text { Hour }\end{array}$ & $\begin{array}{c}\text { Quality of } \\
\text { Labor }\end{array}$ & $\begin{array}{c}\text { Total } \\
\text { Labor } \\
\text { Input }\end{array}$ & $\begin{array}{c}\text { Total } \\
\text { Labor } \\
\text { Hour }\end{array}$ & $\begin{array}{c}\text { Quality of } \\
\text { Labor }\end{array}$ & $\begin{array}{c}\text { Total } \\
\text { Labor } \\
\text { Input }\end{array}$ & $\begin{array}{c}\text { Total } \\
\text { Labor } \\
\text { Hour }\end{array}$ & $\begin{array}{c}\text { Quality of } \\
\text { Labor }\end{array}$ & $\begin{array}{c}\text { Total } \\
\text { Labor } \\
\text { Input }\end{array}$ & $\begin{array}{c}\text { Total } \\
\text { Labor } \\
\text { Hour }\end{array}$ & $\begin{array}{c}\text { Quality } \\
\text { of Labor }\end{array}$ \\
\hline $63-00$ & 3.99 & 2.89 & 1.10 & 2.39 & 2.89 & -0.50 & 3.98 & 2.89 & 1.09 & 3.25 & 2.89 & 0.37 \\
\hline $63-70$ & 4.42 & 3.69 & 0.73 & 3.15 & 3.69 & -0.55 & 5.09 & 3.69 & 1.40 & 3.33 & 3.69 & -0.37 \\
\hline $71-80$ & 5.54 & 4.26 & 1.28 & 3.31 & 4.26 & -0.95 & 4.91 & 4.26 & 0.65 & 5.26 & 4.26 & 1.00 \\
\hline $81-90$ & 3.73 & 2.39 & 1.34 & 1.96 & 2.39 & -0.43 & 3.74 & 2.39 & 1.35 & 2.78 & 2.39 & 0.38 \\
\hline $91-00$ & 2.39 & 1.43 & 0.96 & 1.35 & 1.43 & -0.08 & 2.49 & 1.43 & 1.06 & 1.66 & 1.43 & 0.23 \\
\hline
\end{tabular}

Then, the income figures were used to analyze by what percent labor indexes increased on average annually. Under the assumption that the average annual wage of an unpaid worker is equivalent to $75 \%$ of an employee's, the index of the quality in aggregate volume index of labor input increased by $1.1 \%$ on average annually. Partial index of

\footnotetext{
${ }^{14}$ See the 1997 ILO "Yearbook of Labor Statistics" and the 2001 KNSO “Annual Report on the Economically Active Population Survey".
} 
the quality of education level and industry went up $1.09 \%, 0.37 \%$ respectively, while partial index of the quality of sex fell by $0.5 \%$ (see Table 3 ).

When it was assumed that the average annual wage of an unpaid worker is equivalent to $50 \%$ of an employee's, the index of the quality in aggregate volume index of labor input increased by $1.46 \%$ on average annually. Partial index of the quality of educational level and industry went up $1.11 \%, 0.40 \%$, respectively, while partial index of the quality of sex fell by $0.53 \%$ (see Table 4 ).

Table 4 - Annual Average Growth Rate of Labor Input:

$50 \%$ of the Employees Wage for Unpaid Workers (Unit: \%)

\begin{tabular}{|c|c|c|c|c|c|c|c|c|c|c|c|c|}
\hline & \multicolumn{3}{|c|}{ Aggregate Labor Input } & \multicolumn{3}{|c|}{ Gender Partial Index } & \multicolumn{3}{|c|}{ Education Partial Index } & \multicolumn{3}{c|}{ Industry Partial Index } \\
\hline Year & $\begin{array}{c}\text { Total } \\
\text { Labor } \\
\text { Input }\end{array}$ & $\begin{array}{c}\text { Total } \\
\text { Labor } \\
\text { Hour }\end{array}$ & $\begin{array}{c}\text { Quality } \\
\text { of Labor }\end{array}$ & $\begin{array}{c}\text { Total } \\
\text { Labor } \\
\text { Input }\end{array}$ & $\begin{array}{c}\text { Total } \\
\text { Labor } \\
\text { Hour }\end{array}$ & $\begin{array}{c}\text { Quality of } \\
\text { Labor }\end{array}$ & $\begin{array}{c}\text { Total } \\
\text { Labor } \\
\text { Input }\end{array}$ & $\begin{array}{c}\text { Total } \\
\text { Labor } \\
\text { Hour }\end{array}$ & $\begin{array}{c}\text { Quality of } \\
\text { Labor }\end{array}$ & $\begin{array}{c}\text { Total } \\
\text { Labor } \\
\text { Input }\end{array}$ & $\begin{array}{c}\text { Total } \\
\text { Labor } \\
\text { Hour }\end{array}$ & $\begin{array}{c}\text { Quality of } \\
\text { Labor }\end{array}$ \\
\hline $63-00$ & 4.34 & 2.89 & 1.46 & 2.36 & 2.89 & -0.53 & 4.00 & 2.89 & 1.11 & 3.28 & 2.89 & 0.40 \\
\hline $63-70$ & 4.88 & 3.69 & 1.18 & 3.12 & 3.69 & -0.58 & 5.11 & 3.69 & 1.41 & 3.30 & 3.69 & -0.40 \\
\hline $71-80$ & 6.07 & 4.26 & 1.81 & 3.26 & 4.26 & -1.00 & 4.92 & 4.26 & 0.66 & 5.26 & 4.26 & 1.00 \\
\hline $81-90$ & 4.10 & 2.39 & 1.70 & 1.93 & 2.39 & -0.46 & 3.78 & 2.39 & 1.38 & 2.85 & 2.39 & 0.46 \\
\hline $91-00$ & 2.48 & 1.43 & 1,04 & 1.35 & 1.43 & -0.08 & 2.53 & 1.43 & 1.09 & 1.73 & 1.43 & 0.29 \\
\hline
\end{tabular}

As shown $\langle$ Table 5$\rangle$, the assumption that the average annual wage of an unpaid worker is equivalent to $25 \%$ of an employee's resulted in a $0.56 \%$ decreased the partial index of the quality of sex. However, the index of the quality in aggregate volume index of labor input increased by $1.95 \%$ on average annually and partial index of the quality of education level and industry went up $1.15 \%, 0.43 \%$, respectively.

Table 5 - Annual Average Growth Rate of Labor Input:

$25 \%$ of the Employees Wage for Unpaid Workers (Unit \%)

\begin{tabular}{|c|c|c|c|c|c|c|c|c|c|c|c|c|}
\hline & \multicolumn{3}{|c|}{ Aggregate Labor Input } & \multicolumn{3}{|c|}{ Gender Partial Index } & \multicolumn{2}{c|}{ Education Partial Index } & \multicolumn{3}{c|}{ Industry Partial Index } \\
\hline Year & $\begin{array}{c}\text { Total } \\
\text { Labor } \\
\text { Input }\end{array}$ & $\begin{array}{c}\text { Total } \\
\text { Labor } \\
\text { Hour }\end{array}$ & $\begin{array}{c}\text { Quality } \\
\text { of Labor }\end{array}$ & $\begin{array}{c}\text { Total } \\
\text { Labor } \\
\text { Input }\end{array}$ & $\begin{array}{c}\text { Total } \\
\text { Labor } \\
\text { Hour }\end{array}$ & $\begin{array}{c}\text { Quality } \\
\text { of Labor }\end{array}$ & $\begin{array}{c}\text { Total } \\
\text { Labor } \\
\text { Input }\end{array}$ & $\begin{array}{c}\text { Total } \\
\text { Labor } \\
\text { Hour }\end{array}$ & $\begin{array}{c}\text { Quality } \\
\text { of Labor }\end{array}$ & $\begin{array}{c}\text { Total } \\
\text { Labor } \\
\text { Input }\end{array}$ & $\begin{array}{c}\text { Total } \\
\text { Labor } \\
\text { Hour }\end{array}$ & $\begin{array}{c}\text { Quality } \\
\text { of Labor }\end{array}$ \\
\hline $63-00$ & 4.83 & 2.89 & 1.95 & 2.32 & 2.89 & -0.56 & 4.03 & 2.89 & 1.15 & 3.32 & 2.89 & 0.43 \\
\hline $63-70$ & 5.59 & 3.69 & 1.90 & 3.06 & 3.69 & -0.63 & 5.13 & 3.69 & 1.44 & 3.25 & 3.69 & -0.45 \\
\hline $71-80$ & 6.83 & 4.26 & 2.57 & 3.20 & 4.26 & -1.06 & 4.93 & 4.26 & 0.67 & 5.26 & 4.26 & 1.00 \\
\hline $81-90$ & 4.56 & 2.39 & 2.16 & 1.90 & 2.39 & -0.50 & 3.83 & 2.39 & 1.43 & 2.94 & 2.39 & 0.55 \\
\hline $91-00$ & 2.58 & 1.43 & 1.15 & 1.36 & 1.43 & -0.08 & 2.57 & 1.43 & 1.13 & 1.81 & 1.43 & 0.38 \\
\hline
\end{tabular}

A comparison was made between the $75 \%, 50 \%$, and $25 \%$ assumption-based figures and figures obtained by not applying the $75 \%, 50 \%$, and $25 \%$ assumptions (in which case employment status would not be considered). When it was assumed that the average monthly wage of an unpaid worker is less than an employee's, index of aggregate input increased by minimum $0.2 \%$ and maximum $1.1 \%$ more on average annually than when an opposite assumption was made. The difference was made because the index of quality of labor input went up by minimum $0.3 \%$ and maximum $1.3 \%$ on average annually when assuming a wage difference exists class of employment. 
As explained so far, we can see that the increasing rate became higher in the index of the quality of labor input focused on partial index average annually. The partial index of the quality of educational attainment and industry increased while the partial index of quality of sex became lower when employment status was taken into consideration. This is because employees' educational level is higher compared to unpaid workers and manufacturing and service business that pay attractive salaries are hiring an increasing number of employees.

In Tables 6,7 , and 8 , it was assumed that the average monthly wage of a family worker is $75 \%, 50 \%$ or $25 \%$ of an employee's. Then, labor incomes for family workers were calculated accordingly and the labor income figures were used to analyze by what percent labor indexes increased on average annually. Under the assumption that the average annual wage of a family worker is equivalent to $75 \%$ of an employee's, the index of the quality of aggregate volume input increased by $0.95 \%$ on average annually. The partial index of the educational attainment and industry climbed up $1.3 \%$ and $0.31 \%$, respectively. While the partial index of the quality of sex declined by $0.51 \%$ on average annually (see Table 6).

Table 6 - Annual Average Growth Rate of Labor Input:

75\% of the Employees Wage for Family Workers (Unit: \%)

\begin{tabular}{|c|c|c|c|c|c|c|c|c|c|c|c|c|}
\hline \multirow[b]{2}{*}{ Year } & \multicolumn{3}{|c|}{$\begin{array}{c}\text { Aggregate Labor Input } \\
\text { Index }\end{array}$} & \multicolumn{3}{|c|}{ Gender Partial Index } & \multicolumn{3}{|c|}{ Education Partial Index } & \multicolumn{3}{|c|}{ Industry Partial Index } \\
\hline & $\begin{array}{c}\text { Total } \\
\text { Labor } \\
\text { Input }\end{array}$ & $\begin{array}{c}\text { Total } \\
\text { Labor } \\
\text { Hour }\end{array}$ & $\begin{array}{l}\text { Quality } \\
\text { of Labor }\end{array}$ & $\begin{array}{l}\text { Total } \\
\text { Labor } \\
\text { Input }\end{array}$ & $\begin{array}{c}\text { Total } \\
\text { Labor } \\
\text { Hour }\end{array}$ & $\begin{array}{l}\text { Quality } \\
\text { of Labor }\end{array}$ & $\begin{array}{c}\text { Total } \\
\text { Labor } \\
\text { Input }\end{array}$ & $\begin{array}{c}\text { Total } \\
\text { Labor } \\
\text { Hour }\end{array}$ & $\begin{array}{l}\text { Quality } \\
\text { of Labor }\end{array}$ & $\begin{array}{c}\text { Total } \\
\text { Labor } \\
\text { Input }\end{array}$ & $\begin{array}{c}\text { Total } \\
\text { Labor } \\
\text { Hour }\end{array}$ & $\begin{array}{c}\text { Quality } \\
\text { of } \\
\text { Labor }\end{array}$ \\
\hline $63-00$ & 3.83 & 2.89 & 0.95 & 2.37 & 2.89 & -0.51 & 3.99 & 2.89 & 1.10 & 3.20 & 2.89 & 0.31 \\
\hline $63-70$ & 4.24 & 3.69 & 0.54 & 3.12 & 3.69 & -0.58 & 5.11 & 3.69 & 1.41 & 3.30 & 3.69 & -0.39 \\
\hline $71-80$ & 5.14 & 4.26 & 0.88 & 3.30 & 4.26 & -0.96 & 4.92 & 4.26 & 0.66 & 5.24 & 4.26 & 0.98 \\
\hline $81-90$ & 3.66 & 2.39 & 1.27 & 1.95 & 2.39 & -0.44 & 3.75 & 2.39 & 1.36 & 2.67 & 2.39 & 0.27 \\
\hline $91-00$ & 2.41 & 1.43 & 0.98 & 1.35 & 1.43 & -0.09 & 2.51 & 1.43 & 1.08 & 1.62 & 1.43 & 0.18 \\
\hline
\end{tabular}

Under the assumption that the average annual wage of a family worker is equivalent to $50 \%$ of an employee's, the index of the quality of aggregate volume input increased by $1.06 \%$ on average annually. The partial index of the educational attainment and industry climbed up $1.13 \%$ and $0.29 \%$, respectively. While the partial index of the quality of sex declined by $0.55 \%$ on average annually (<see Table $7>$ ).

Table 7 - Annual Average Growth Rate of Labor Input: $50 \%$ of the Employees Wage for Family Workers (Unit: \%)

\begin{tabular}{|c|c|c|c|c|c|c|c|c|c|c|c|c|}
\hline & \multicolumn{3}{|c|}{ Aggregate Labor Input } & \multicolumn{3}{|c|}{ Gender Partial Index } & \multicolumn{3}{l|}{ Education Partial Index } & \multicolumn{3}{|c|}{ Industry Partial Index } \\
Index
\end{tabular}


Lastly, under the assumption that the average annual wage of a family worker is equivalent to $25 \%$ of an employee's, the index of the quality of aggregate volume input increased by $1.18 \%$ on average annually. The partial index of the educational attainment and industry climbed up $1.17 \%$ and $0.26 \%$, respectively. While the partial index of the quality of sex declined by $0.59 \%$ on average annually (<see Table $8>$ ).

Table 8 - Annual Average Growth Rate of Labor Input:

$25 \%$ of the Employees Wage for Family Workers (Unit: \%)

\begin{tabular}{|c|c|c|c|c|c|c|c|c|c|c|c|c|}
\hline \multirow[b]{2}{*}{ Year } & \multicolumn{3}{|c|}{$\begin{array}{c}\text { Aggregate Labor Input } \\
\text { Index }\end{array}$} & \multicolumn{3}{|c|}{ Gender Partial Index } & \multicolumn{3}{|c|}{ Education Partial Index } & \multicolumn{3}{|c|}{ Industry Partial Index } \\
\hline & $\begin{array}{l}\text { Total } \\
\text { Labor } \\
\text { Input }\end{array}$ & $\begin{array}{c}\text { Total } \\
\text { Labor } \\
\text { Hour }\end{array}$ & $\begin{array}{l}\text { Quality } \\
\text { of Labor }\end{array}$ & $\begin{array}{l}\text { Total } \\
\text { Labor } \\
\text { Input }\end{array}$ & $\begin{array}{c}\text { Total } \\
\text { Labor } \\
\text { Hour }\end{array}$ & $\begin{array}{l}\text { Quality } \\
\text { of Labor }\end{array}$ & $\begin{array}{l}\text { Total } \\
\text { Labor } \\
\text { Input }\end{array}$ & $\begin{array}{c}\text { Total } \\
\text { Labor } \\
\text { Hour }\end{array}$ & $\begin{array}{l}\text { Quality } \\
\text { of Labor }\end{array}$ & $\begin{array}{l}\text { Total } \\
\text { Labor } \\
\text { Input }\end{array}$ & $\begin{array}{c}\text { Total } \\
\text { Labor } \\
\text { Hour }\end{array}$ & $\begin{array}{l}\text { Quality } \\
\text { of Labor }\end{array}$ \\
\hline $63-00$ & 4.07 & 2.89 & 1.18 & 2.29 & 2.89 & -0.59 & 4.06 & 2.89 & 1.17 & 3.14 & 2.89 & 0.26 \\
\hline $63-70$ & 4.56 & 3.69 & 0.86 & 2.99 & 3.69 & -0.70 & 5.16 & 3.69 & 1.46 & 3.19 & 3.69 & -0.50 \\
\hline $71-80$ & 5.12 & 4.26 & 0.86 & 3.17 & 4.26 & -1.09 & 4.95 & 4.26 & 0.68 & 5.21 & 4.26 & 0.94 \\
\hline $81-90$ & 4.14 & 2.39 & 1.75 & 1.88 & 2.39 & -0.51 & 3.85 & 2.39 & 1.45 & 2.55 & 2.39 & 0.16 \\
\hline $91-00$ & 2.60 & 1.43 & 1.17 & 1.34 & 1.43 & -0.09 & 2.60 & 1.43 & 1.17 & 1.64 & 1.43 & 0.20 \\
\hline
\end{tabular}

A comparison was made under the assumption that the average annual wage of a family worker is equivalent to $75 \%, 50 \%$, and $25 \%$ of an employee's, and by not applying the $75 \%, 50 \%$ and $25 \%$ assumptions. When it was assumed that the average monthly wage of a family worker is less than an employee's or the self-employed, the index of the aggregate volume input rose by minimum. $0.1 \%$ and maximum. $0.4 \%$ more on average annually than when an opposite assumption was made. The difference is attributable to the fact that assuming a wage difference between employment statuses resulted in greater increase in index of the quality of labor input on average annually.

A more thorough examination tells us that the partial index of the quality of education level and industry increased but the partial index of the quality of sex decreased when taking into account employment status. That average annual increases in the aggregate volume index of labor input were smaller when considering only family workers than when considering unpaid workers. It is probably because the proportion of family workers to the total workforce was relatively small. Therefore, I can conclude that the improvement of labor quality stemming from changes in employment status also had a considerable influence on human capital accumulation in Korea between 1963 and 2000.

\section{CONCLUSIONS}

Worldwide, human capital stock has been measured based on products by using school enrollment, educational attainment, adult literacy, and average years of schooling as proxy variables, by adding up all investments in human capital, by using weighted values of quality indexes of the workforce. In this study, an empirical analysis was conducted by measuring human capital stock on the basis of labor incomes. I analyzed data on the number of workers, labor hours, wages by industry, sex, and educational attainment level from 1963 to 2000 in order to measure Korea's human capital stock. In addition, human capital stock was further classified by class of employment (either employee or unpaid worker).

When index of the labor input was calculated by applying same average monthly wages to all workers regardless of their class of employment, the aggregate volume index of labor input went up by $3.73 \%$ and the index of the quality of labor increased slightly by $0.84 \%$ on average annually between 1963 and 2000 . Therefore, I can see that $23.0 \%$ of all increases in aggregate volume index of labor input for the observation period was brought about by improved labor quality or human capital accumulation. 
Between 1963 and 2000, changes in educational level resulted in average 1.07\% increases in the quality index annually, thereby contributing more to quality index increases than any other factors. This leads to a conclusion that strong emphasis on education, more learning opportunities and better conditions for education were the driving force behind human capital accumulation in Korea.

Human capital stock is usually broken down into two types: school education-based and non-school education-based. The latter includes on-the-job training and learning by doing. According to a study, school education accounted for $64.0 \%$ of total human capital increase with on-the-job-training making up the remaining 36.0\% in the United States between 1909 and 1957 (Lucas, 1988). Kim and Park estimated in 1985 that in Korea, onthe-job-training was responsible for a $3.81 \%$ increase in human capital easily beating school education accounting for $0.72 \%$ between 1963 and 1982. It was estimated that school education and on-the-job-training boosted Korea's human capital by $16.0 \%$ and $64.0 \%$, respectively.

So, I cannot say that this study correctly measured Korea's human capital stock accumulated between 1963 and 2000 because it excluded on-the-job-training, etc., in consideration of the aforementioned characteristics of the domestic human capital. The exclusion was made not only because it was not possible to get enough data on-the-jobtraining and learning by doing in Korea but also because consistency of time series data could not be ensured. Therefore, priority should be given to systematic collection, classification, etc., of data and creation of basic data at the national level.

I'm indebted to many participants at the 2003 meeting of the International Business \& Economics Research Conference (Acapulco, Mexico) for helpful comments and suggestions on earlier drafts of this paper.

\section{REFERENCES}

1. Barro, R. J. (1991), "Economic growth in a cross-section of countries", Quarterly Journal of Economics, 106, 407-443.

2. Barro, R. J. (1997), Determinants of economic growth: across country empirical study, Cambridge, MA: MIT Press.

3. Barro, R. J. and Jong - Wha Lee (1993), "International comparisons of educational attainment", Journal of Monetary Economics, 32, 363-394.

4. Baumol, W. J. (1986), "Productivity growth, convergence, and welfare: What the long-run data show", American Economics Review, 76, 1072-1085.

5. Becker, G. S. (1964), "Human Capital: A theoretical and empirical analysis, with special reference to education", New York: National Bureau of Economic Research.

6. Becker, G. S., K. M. Murphy and R. Tamura (1990), "Human capital, fertility, and economic growth", Journal of Political Economy, 98(5), S12-37.

7. $\quad$ Becker, G. S., (1995), "Human capital and economic growth", Prague papers, 4(3), 223-228.

8. Benhabib, J. and Spiegel, M. M. (1994), "The role of human capital in economic development: Evidence from cross-country data", Journal of Monetary Economics, 34, 143-73.

9. Box, G. E. P. and G. M. Jenkins (1976), Time series analysis: forecasting and control, Holden-Day, San Francisco.

10. Collins, S. and Bosworth, B. (1996), "Economic growth in East Asia: Accumulation versus assimilation", Brookings Papers on Economic Activity, 2, 135-203.

11. Denision, E. F. (1985), Trends in American economic growth, 1929- 1982, Washington. D.C.: Brooking Institute.

12. Engle, R. F. and C. W. J. Granger (1987), "Co-integratation and error-correction: Representation, estimation and testing". Econometrica, 35, 251-276.

13. Foster, A. D. and Mark, R. R. (1995), "Learning by doing and learning from others: Human capital and technical change in agriculture", Journal of political Economy, 103, 113-126.

14. Gollop, F. M. and Jorgenson, D. W. (1980), “U. S. productivity growth by industry, 1947-1973”, in New development in productivity Measurement, (eds.) by J. Kendrick and B. Vaccara, The University of Chicago Press, 17-136. 
15. Helliwell, J. E. (1996), "Economic growth and social capital in Asia”, NBER Working Paper No. 5470, Cambridge, MA: National Bureau of Economic Research.

16. Jacobs, J. (1984), Cities and wealth of national, New York, Random House.

17. Jones, C. (1995), "Time-series tests of endogenous growth models", Quarterly Journal of Economics, 110, 495-525.

18. Jorgenson, D., Gollop, F. and Fraumeni, B (1987), Productivity and U.S. Economic Growth, Cambridge, Harvard University Press.

19. Kim, K. S. and J. K. Park (1985), Sources of Economic Growth in Korea: 1963-1982, Korea Development Institute, Seoul.

20. Lee, G. H. and Hart, J. D. (2000), "Model selection criteria with data dependent penalty and data driven newman smooth tests", Journal of Nonparametric statistics, 48, 34-48.

21. Lee, G. H. and Hart, J. D. (1999), "Wavelets and Wavelet estimation: A review", Journal of Economic Theory and Econometrics, 4(1), 123-157.

22. Lee, J. W. and R. J. Barro (1997), "Schooling quality in across-section of countries", NBER Working Paper 6198, Cambridge, MA: National Bureau of Economic Research.

23. Lee, J. W. and S. B. Kim (1995), "Estimates of human capital (1963-1993)" Presented Korea International Economic Conference (1995), 599-637 (Korean).

24. Lee, N. C. and G. H. Lee (2000), Measuring human capital Stock during the 1963-2000. Seoul, KRIVET (Korean).

25. Lee, N. C. (1999), "Human capital and convergence in economic growth in Korea", Journal of International Economic Studies, 13(1), 101-115.

26. Maglen,L. R. (1990), "Challenging the human capital orthodoxy: The education productivity link reexamined", Economic Record, 66, 281-294.

27. Mankiw, N. G. (1995), "The growth of nations", Brookings Paper on Economic Activity, 25, 275-310.

28. Mankiw, N. G, D. Romer., \& D. Weil (1992), "A contribution to the empirics of economic growth", Quarterly Journal of Economics, 107, 407-438.

29. Mincer, J. (1989), "Human capital and the labor market: A review of current research", Educational Researcher, 18(4), 27-34.

30. Mulligan, C. and Xivier Sala-i-Martin (1997), "A labor-income-based measure of the value of human capital: An application to the States of the United States", Japan and the World Economy, 9(2), 159-199.

31. Mulligan, C. and Xivier Sala-i-Martin (1995), "Measuring aggregate human capital", NBER Working Paper No. 5016, Cambridge, MA: National Bureau of Economic Research.

32. Nehru, V., Swanson, E. and Dubey, A. (1993), "A new database on human capital stock sources, methodology, and result", Working Paper No. 1124, Washington, D.C.,: World Bank.

33. OECD (1998), "Human capital investment: An international comparison", Paris.

34. Psacharopoulos, G. (1993), "Return to investment in education: A global update", Washington, D.C.: World Bank.

35. Romer, P. M. (1990), "Endogenous technological change”, Journal of Political Economy, 98, S71- S102.

36. Romer, P. M. (1989), "Capital and growth: Theory and evidence", NBER Working No. 3173, Cambridge, MA: National Bureau of Economic Research, 1989.

37. Romer, P. M. (1986), "Increasing returns and long-run growth", Journal of political Economy, 94, 1002-1037.

38. Sachs, J. and A. Warner (1995), "Economic reform and the process of global integration", Brookings Papers on Economic Activity, 1, 1-118.

39. Schultz, T. P. (1994), "Human capital, family planning, and their effects on population growth", American Economic Review 84(2), 255-260.

40. Schultz, T. W. (1961), "Reflections on investment in man", Journal of Political Economy 70(5, Part 2, Supplement), 1-8.

\section{APPENDIX: DATA}

Two data sources were employed in this paper. Number of workers include the self-employed and family workers as well as percent and temporary employees. I need to cross-classify the work force into 270 different categories by 
industry, sex, educational attainment, and class of employment. I obtain data on hours workers and wage rates by industry, sex, and educational attainment from the below appendix table.

Table A1 - Statistical Sources of Number of Workers

\begin{tabular}{|c|c|c|c|}
\hline Sources & Publisher & Contents & Limitation of data \\
\hline $\begin{array}{l}\text { Annual } \\
\text { Report on } \\
\text { Economic } \\
\text { Activity }\end{array}$ & $\begin{array}{l}\text { National } \\
\text { Statistical } \\
\text { Office }\end{array}$ & $\begin{array}{l}\text { - Provides the number of workers in the total } \\
\text { population aged } 14 \text { and over } 1963 \text {. } \\
\text { - Classifies the work force into } 9 \text { industries, } 2 \\
\text { sexes, } 4 \text { educational level (primary, middle } \\
\text { school, high school, college) and } 2 \text { classes of } \\
\text { employment since } 1984 \text {. } \\
\text { - Classified the } 5 \text { industries (agriculture, } \\
\text { mining, manufacturing, construction, service) } \\
\text { from } 1963 \text { to } 1983 \text {. }\end{array}$ & $\begin{array}{l}\text { - Did not report the number of workers by } \\
\text { educational level and classified the work force } \\
\text { into } 5 \text { industries before } 1983 \text {. }\end{array}$ \\
\hline $\begin{array}{l}\text { Survey } \\
\text { Report on } \\
\text { Establishme } \\
\text { nt Labor } \\
\text { Conditions }\end{array}$ & $\begin{array}{l}\text { Ministry of } \\
\text { Labor }\end{array}$ & $\begin{array}{l}\text { - Focus on companies more than } 5 \text { employees. } \\
\text { - Extract the number of workers except } \\
\text { agriculture, fishery and manufacturing. }\end{array}$ & $\begin{array}{l}\text { - Excluded the number of workers by } \\
\text { educational level. } \\
\text { - Excluded the number of workers by unpaid } \\
\text { worker and less than } 5 \text { employees. }\end{array}$ \\
\hline $\begin{array}{l}\text { Survey } \\
\text { Report on } \\
\text { Wage } \\
\text { Structure }\end{array}$ & $\begin{array}{l}\text { Ministry of } \\
\text { Labor }\end{array}$ & $\begin{array}{l}\text {-Provides the number of workers cross- } \\
\text { classified by sex, industry, class of } \\
\text { employment, and educational attainment. }\end{array}$ & $\begin{array}{l}\text { - Only focused on manufacturing industry more } \\
\text { than } 5 \text { employees. }\end{array}$ \\
\hline $\begin{array}{l}\text { Report on } \\
\text { Mining and } \\
\text { Manufacturi } \\
\text { ng Survey }\end{array}$ & $\begin{array}{l}\text { National } \\
\text { Statistical } \\
\text { Office }\end{array}$ & $\begin{array}{l}\text {-Survey on the mining and manufacturing } \\
\text { companies more than } 5 \text { employees. }\end{array}$ & $\begin{array}{l}\text {-Not included except mining and manufacturing } \\
\text { industries. }\end{array}$ \\
\hline $\begin{array}{l}\text { Report on } \\
\text { Population } \\
\text { and Housing } \\
\text { Census }\end{array}$ & $\begin{array}{l}\text { National } \\
\text { Statistical } \\
\text { Office }\end{array}$ & $\begin{array}{l}\text { - Classifies the work force into } 3 \text { categories, } \\
\text { namely, as elementary, secondary and higher } \\
\text { education. } \\
\text { - Method: break down the number of workers } \\
\text { with secondary education into middle and high } \\
\text { school, workers with higher education into } \\
\text { junior college and college. }\end{array}$ & $\begin{array}{l}\text { - A limited number of data because it is available } \\
\text { at } 5 \text { year interval since } 1960 .\end{array}$ \\
\hline
\end{tabular}

Table A2 - Statistical Sources of Hours Worked and Wages

\begin{tabular}{|l|l|l|l|}
\hline \multicolumn{1}{|c|}{ Sources } & \multicolumn{1}{|c|}{ Contents } & \multicolumn{1}{c|}{ Limitation of data } & \multicolumn{1}{c|}{ Publisher } \\
\hline $\begin{array}{l}\text { Survey } \\
\text { Report on } \\
\text { Wage } \\
\text { Structure }\end{array}$ & $\begin{array}{l}\text { - Use monthly labor hour classified } \\
\text { by industry, sex and educational } \\
\text { attainment and total monthly wages } \\
\text { (manufacturing, mining, service } \\
\text { industry). }\end{array}$ & $\begin{array}{l}\text {-Is not compatible with well-known } \\
\text { actual trend. }\end{array}$ & Ministry of Labor \\
& $\begin{array}{l}\text { - Assume that hours worked over } \\
1963-1970 \text { are the same as those in } \\
1971 .\end{array}$ & & \\
\hline $\begin{array}{l}\text { Annual } \\
\text { Report Labor } \\
\text { Statistics }\end{array}$ & $\begin{array}{l}\text { - Wages consist of monthly wage, } \\
\text { extra labor income and annual } \\
\text { bonus since 1971. }\end{array}$ & $\begin{array}{l}\text { - Classified only by industry } \\
\text { excluded by sex and educational } \\
\text { level. }\end{array}$ & Ministry of Labor \\
& - Assume that hours worked over \\
$1963-1970$ are the same as those in & & \\
\hline $\begin{array}{l}\text { Annual } \\
\text { Economic } \\
\text { Activity }\end{array}$ & - Weekly labor hours (agriculture, & - Available data weekly labor hours \\
fishery) classified by industry. & Ministry of Labor & \\
\hline
\end{tabular}

